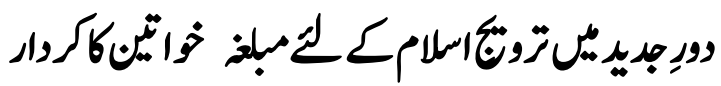

\section{The Role of Preachers Women in Spreding Islam in the Modern Age}

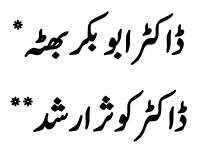

\begin{abstract}
In the present era, there is need for preaching services and it is the duty of all Muslims. If we glance into the globe then at this present time, Muslims are all over the world but they are the meekest and inferiority-complex nations of the world and the majority of Muslims is thinking that their progress is in the culture and civilization of foreigners. At this present time, the Muslims are in miserable plight. In Afghanistan, Iraq, philistine and Kashmir, the Muslims are going through the atrocities.
\end{abstract}

The infidel powers are criticizing the Muslims and Islam, focusing on their own objections on the Islam. Along with the jihad and extremism, the Islam is being criticized on the basis of the women right too. If it is said that, the topic of "woman" is the best topic of criticism on Islam then it wouldn't be wrong. And to highlight this topic, one group of Muslim women is very active and as the women is an important part of society as well the representative of the half humanity then it is clear that the misunderstandings which can be created by the women, more than it the woman can be the best reformer. This reformation is possible only in this way that Muslim should act upon Islam and its teachings.

The women are important member of the society, the reformation of the society is impossible without the women. The reformation of the woman is the reformation of whole family and the reformation of one family is the reformation of the whole society. The role of women is very important in the preaching. Woman, as a mother, after nourishing his children in a better way can keep the base of a good Islamic society after making them a good Muslim and a good society can be the reason of a good global brotherhood.

This article is consisted on two main discussions:

First: the historical background and need for women preachers in the present era Second: the limitations and rules for women preachers in the present era.

Keywords: Women Preachers; Present Era; Reformating; Limitaitons; Rules

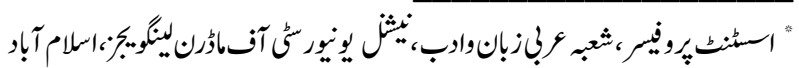

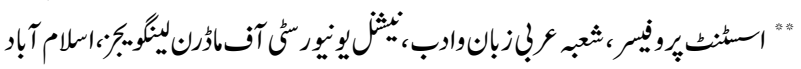




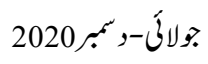

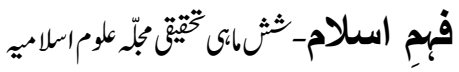

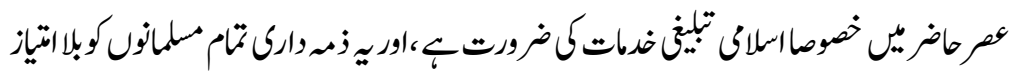

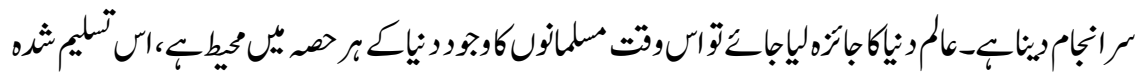

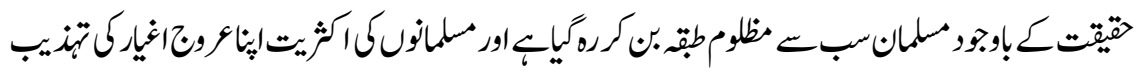

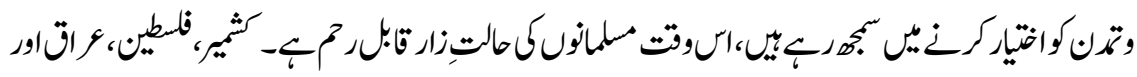

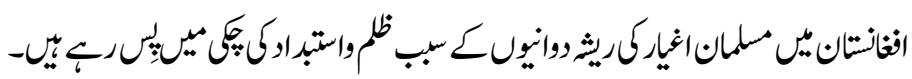

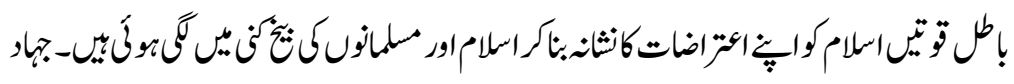

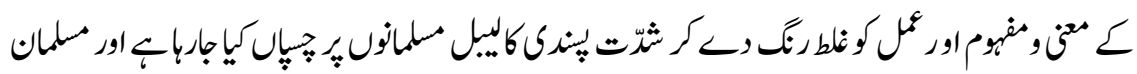

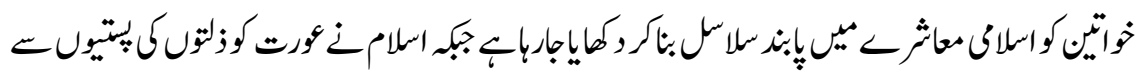

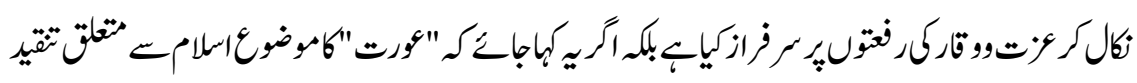

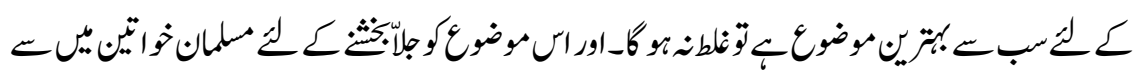

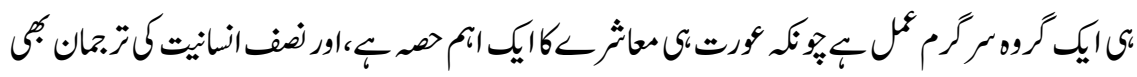

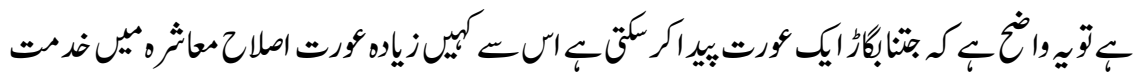

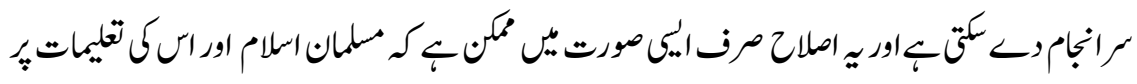

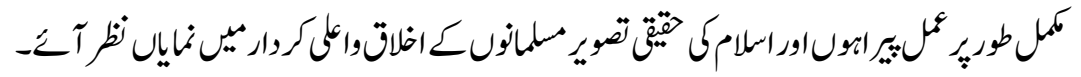

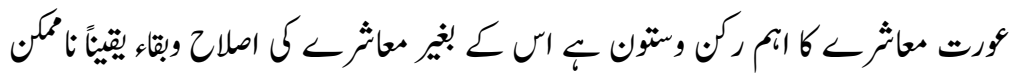

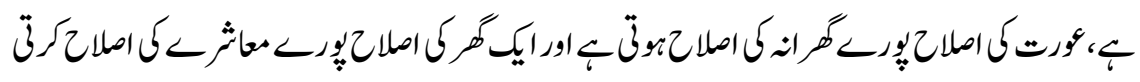

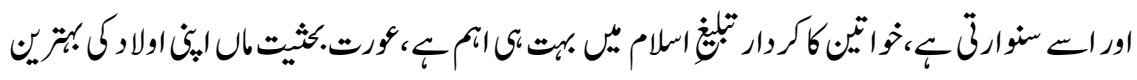

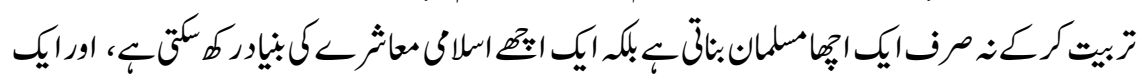

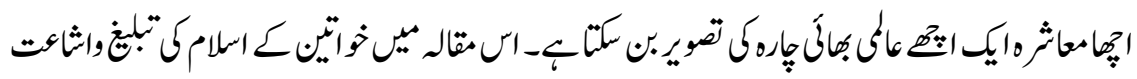

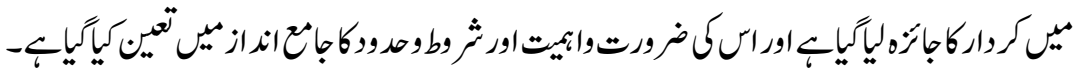

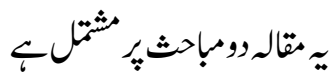

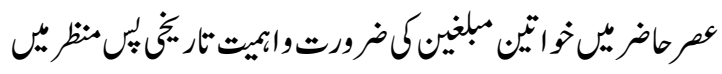

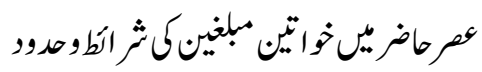

62 


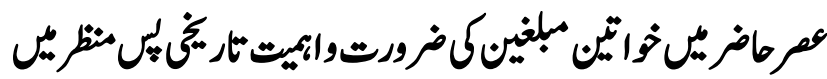

\section{مبلغواثينكمنرورتوايميت}

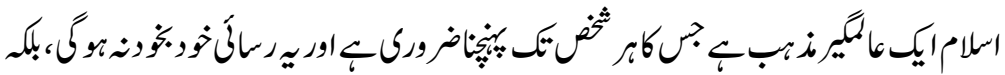

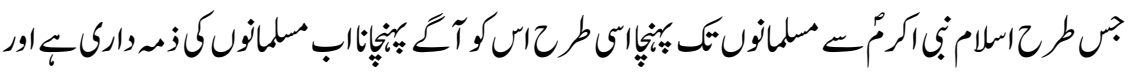

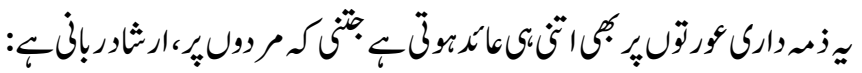

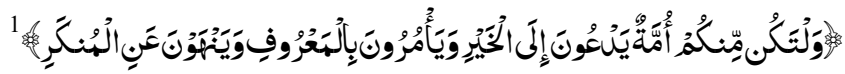

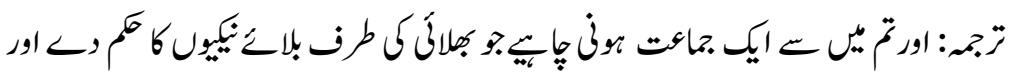

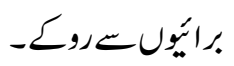

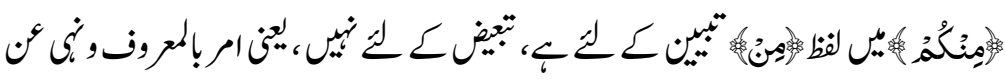

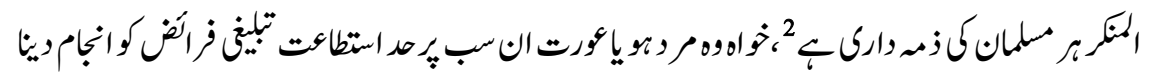

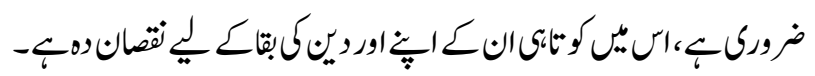

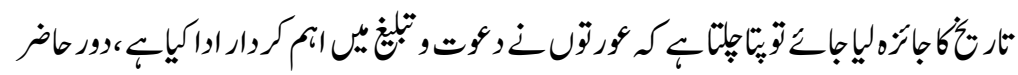

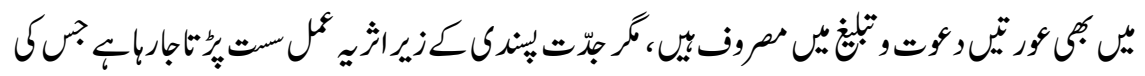

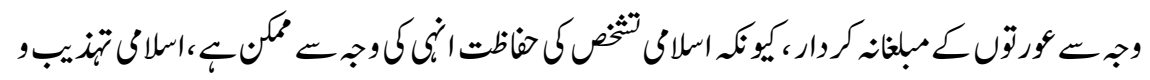

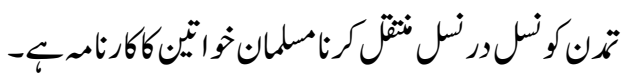

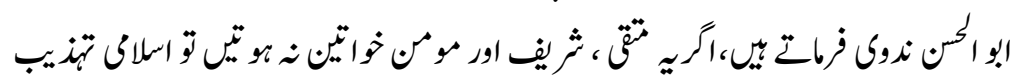

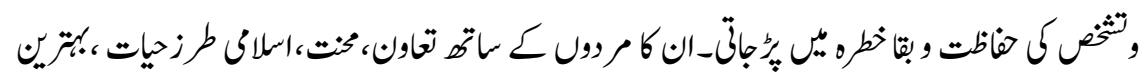

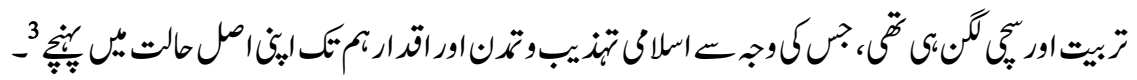

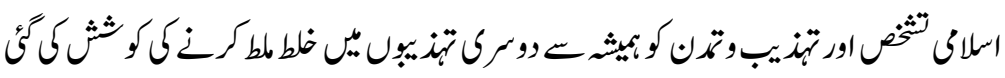

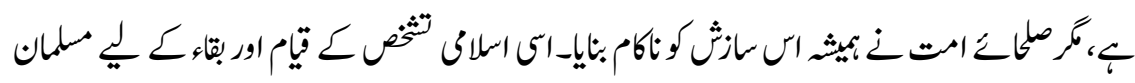

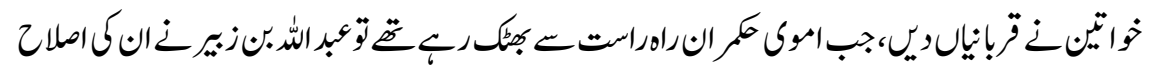

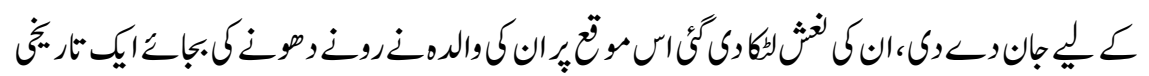




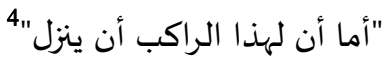

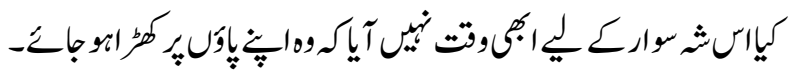

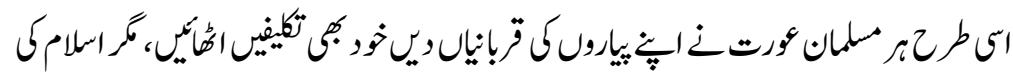

$$
\text { ثناختير حفن آنـريا }
$$

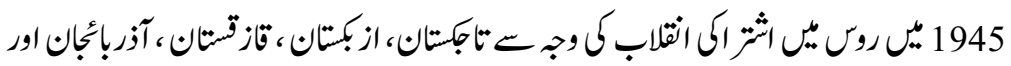

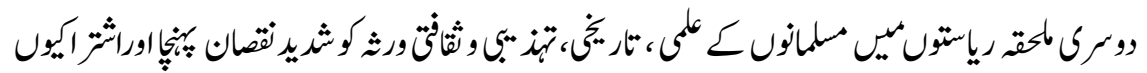

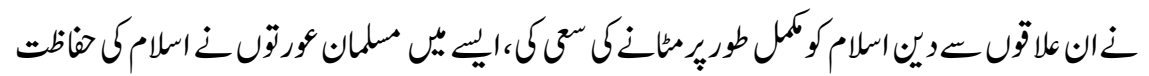

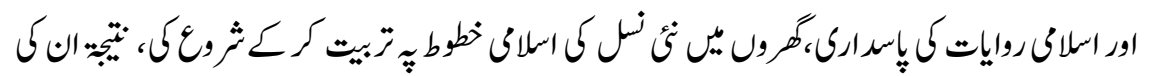

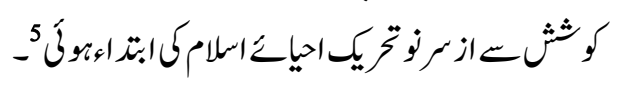

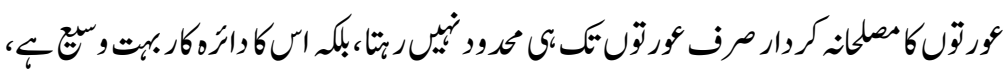

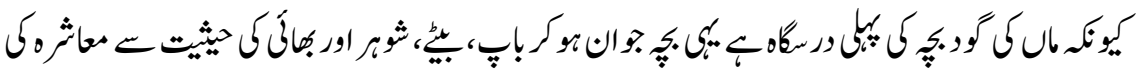

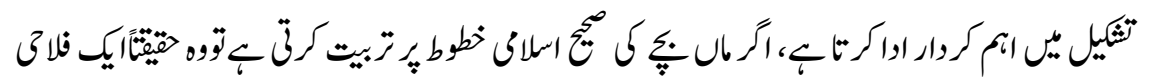

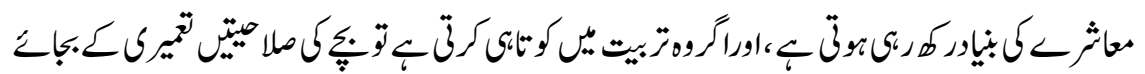

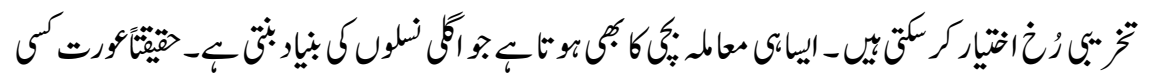

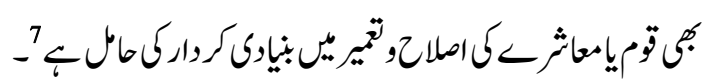

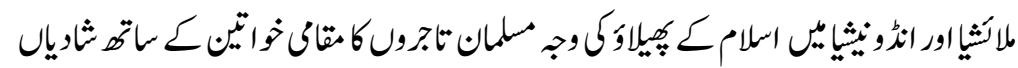

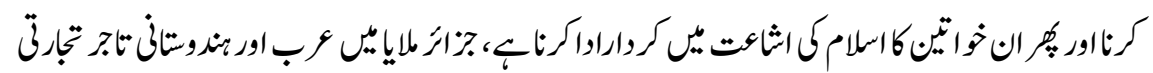

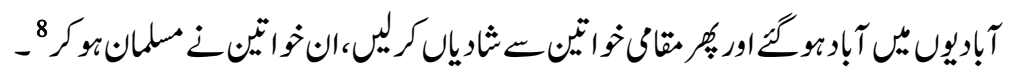

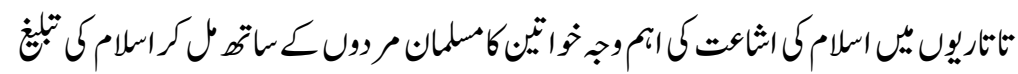

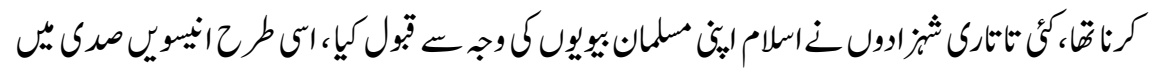

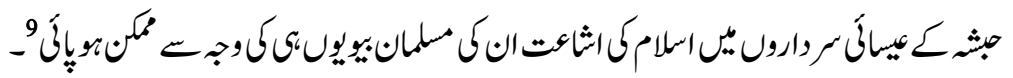

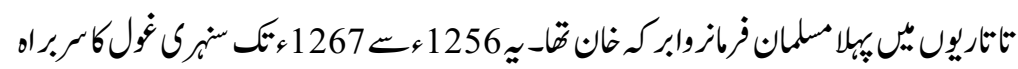

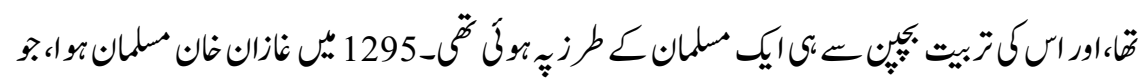

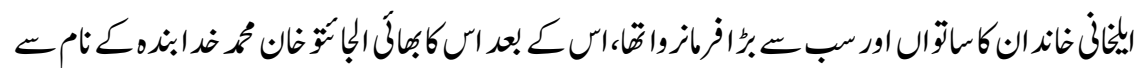




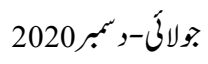

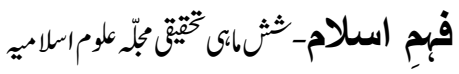

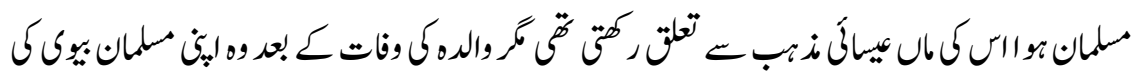

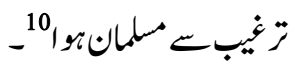

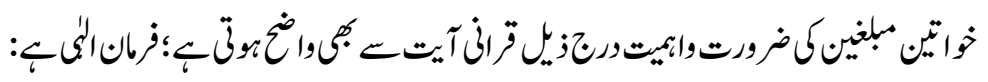

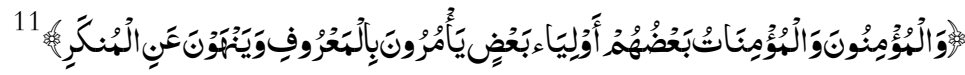

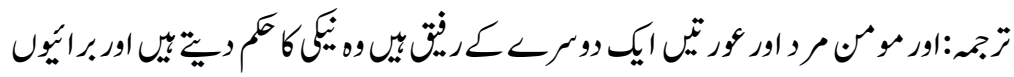

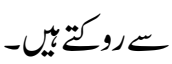

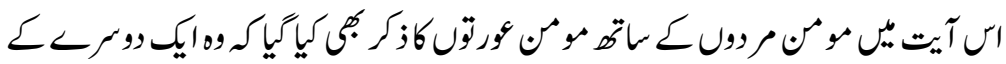

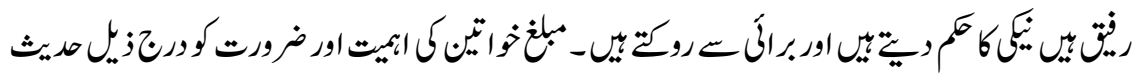

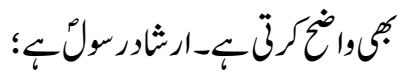

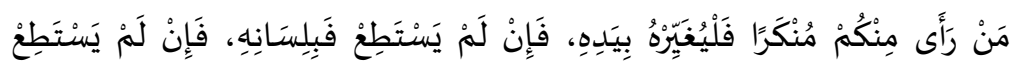

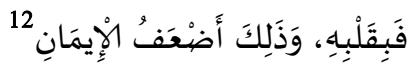

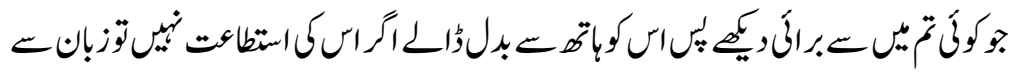

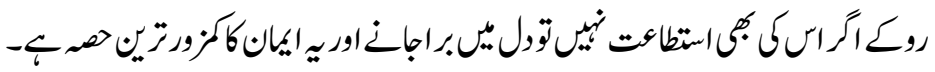

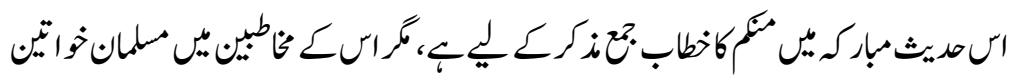

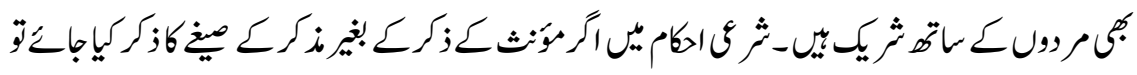

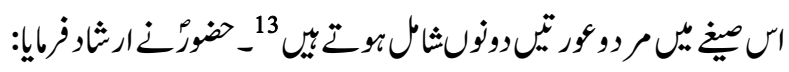

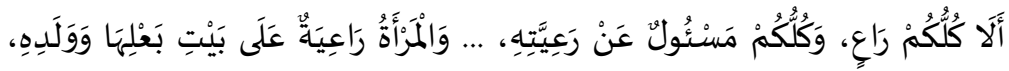

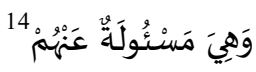

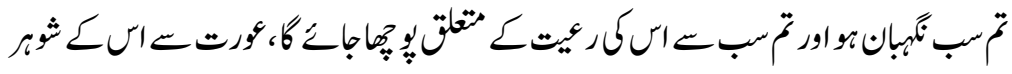

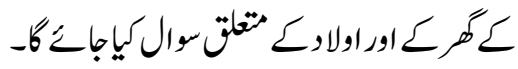

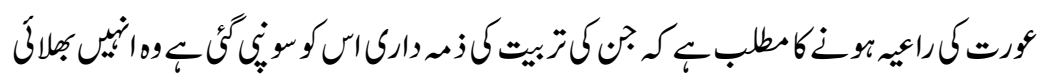

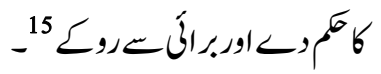

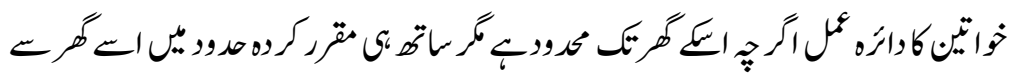

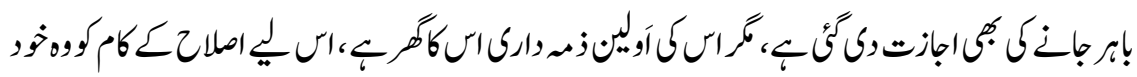

65 


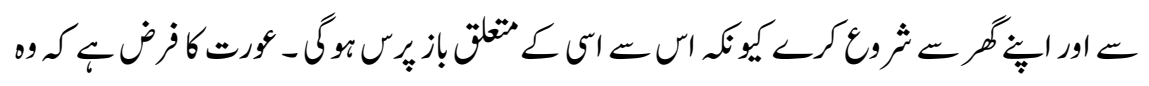

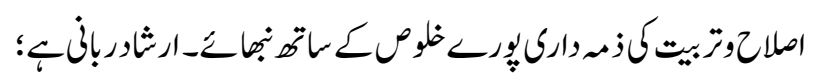

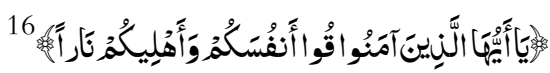

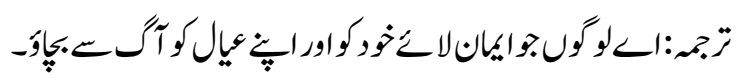

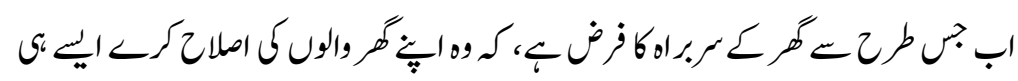

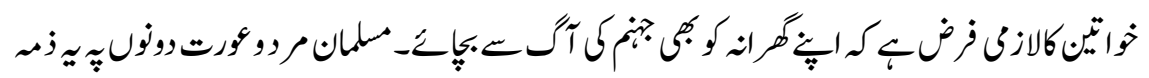

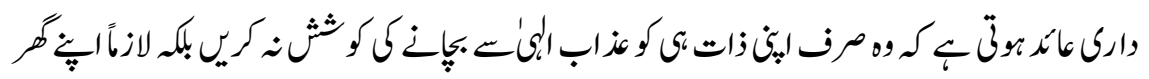

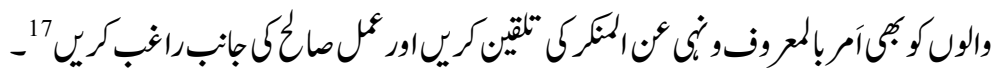

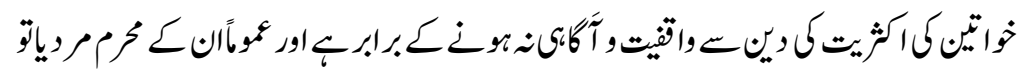

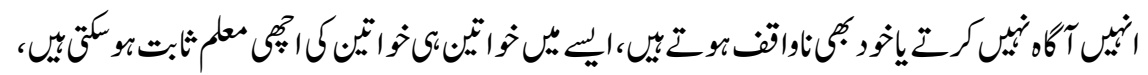

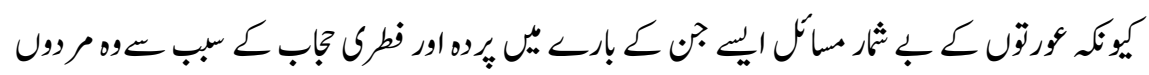

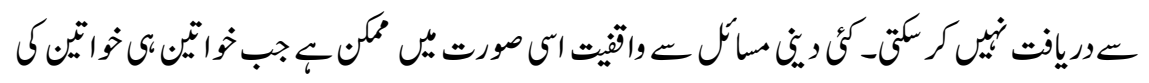
-18 بr

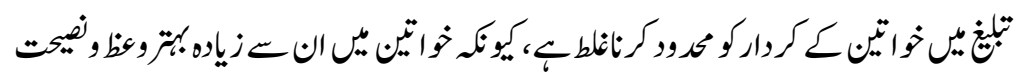

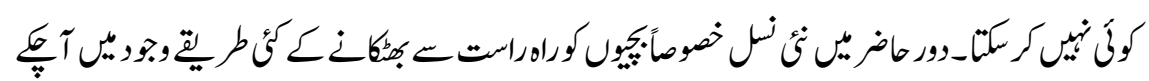

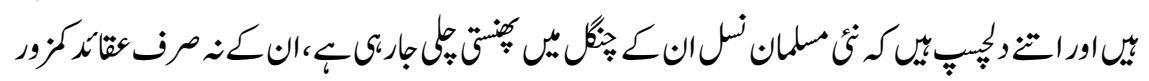

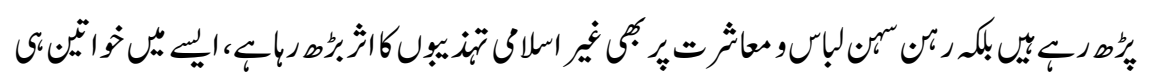

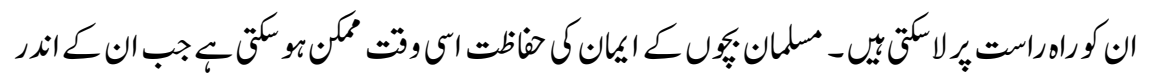

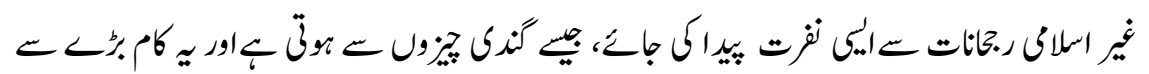

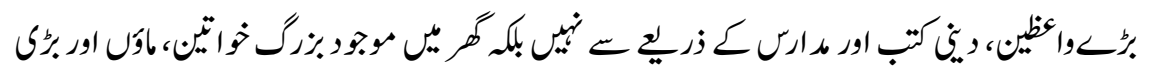

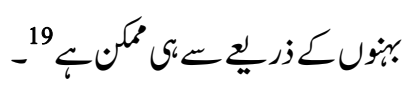

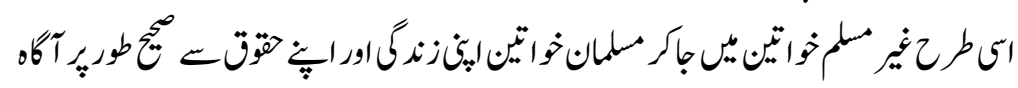

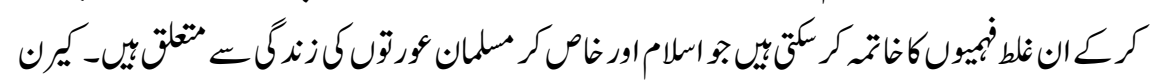

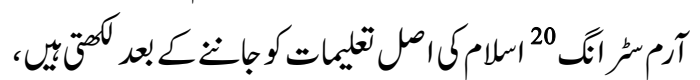


"The women of the first ummah in Medina took full part in its public life, and some, according to Arab custom, fought alongside the men in battle. They did not seem to have experienced Islam as an oppressive religion though later, as happened in Christianity, men would hijack the faith and bring it into line with the prevailing patriarchy". ${ }^{21}$

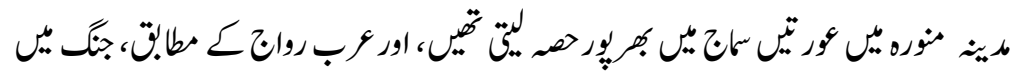

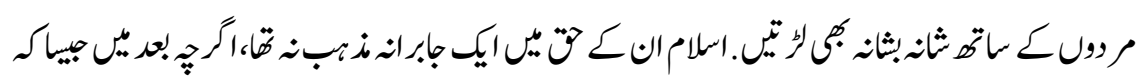

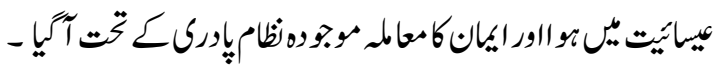

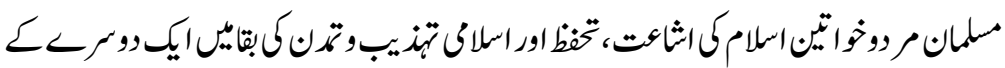

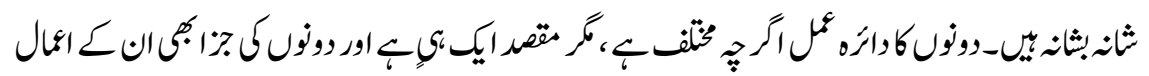

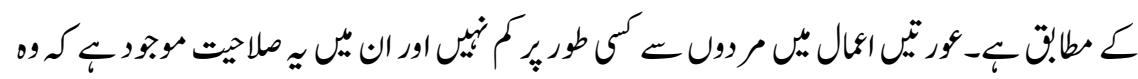

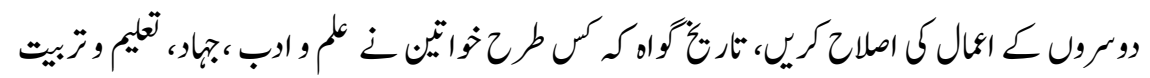

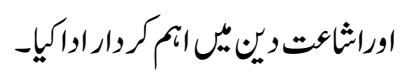

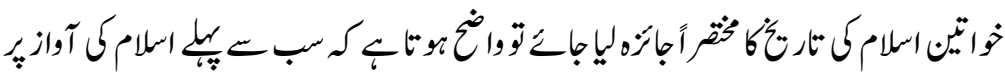

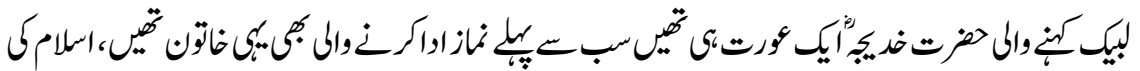

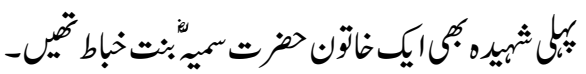

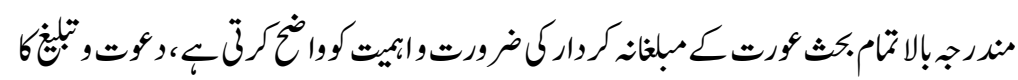

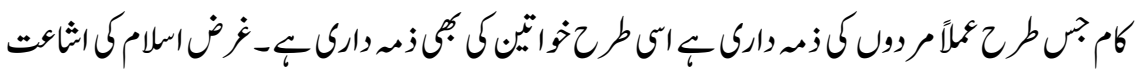

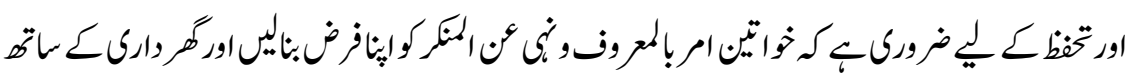

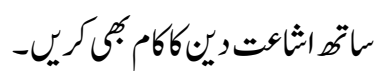

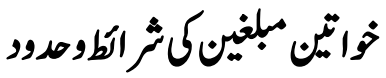

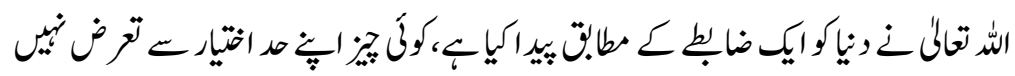

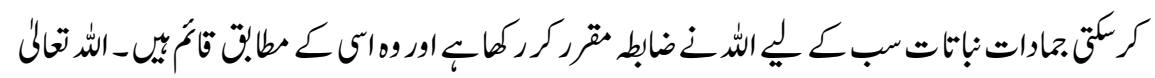

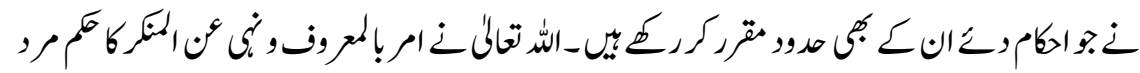

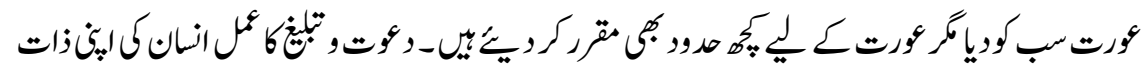




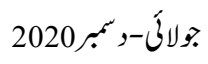

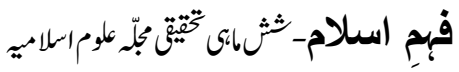

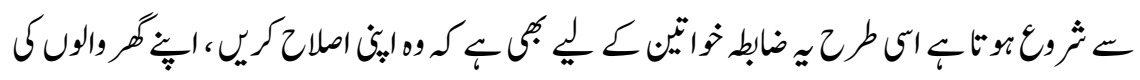

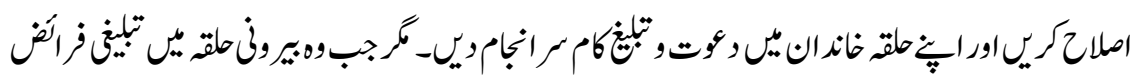

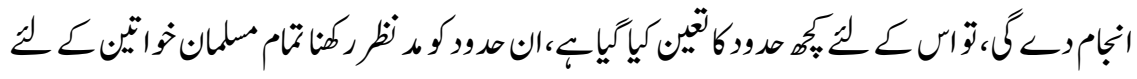

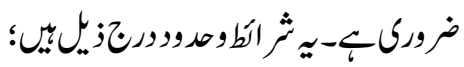

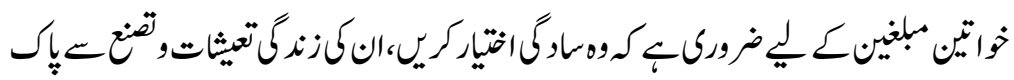

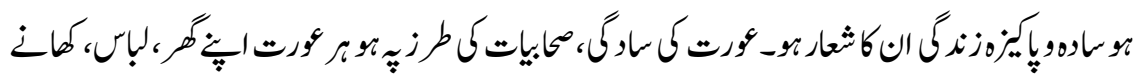

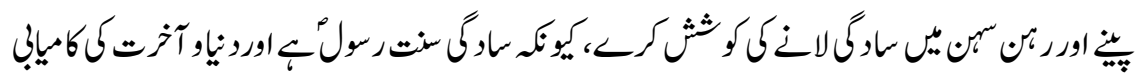

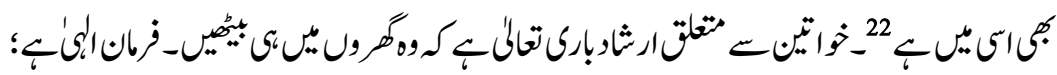

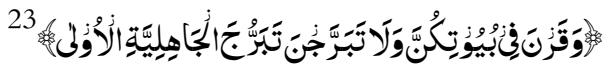

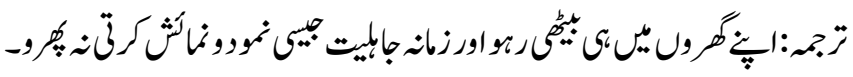

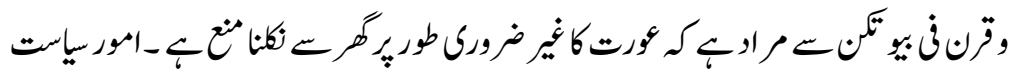

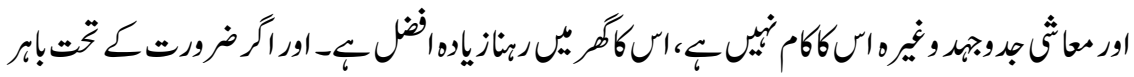

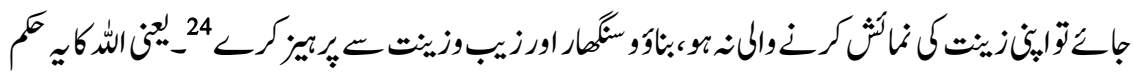

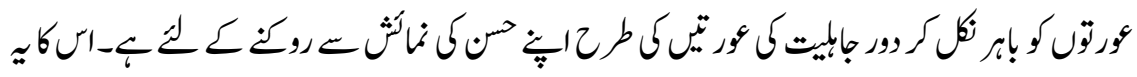

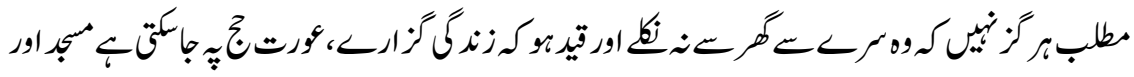

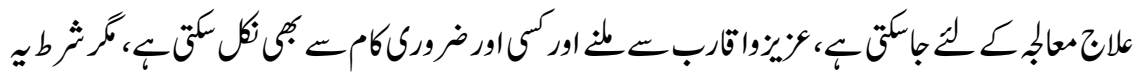

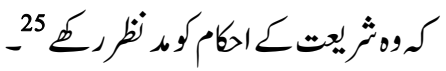

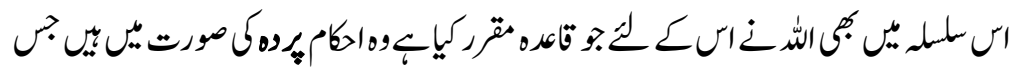

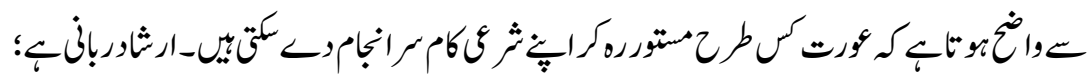

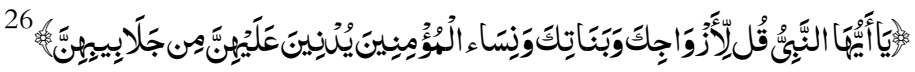

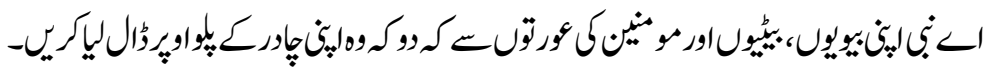

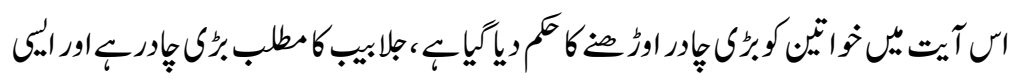

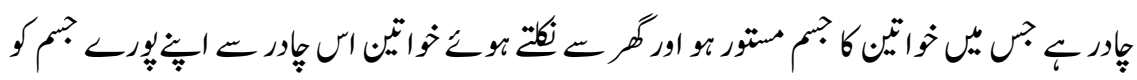

ؤمان:

68 
"الجلابيب وهي الملحفة التى تشتمِل بها المرأة أي يُرخين بعضها على الوجوه إذا

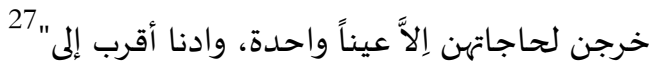

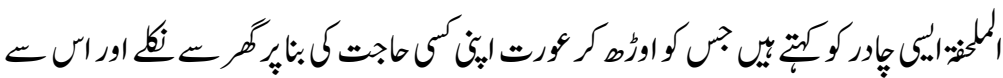

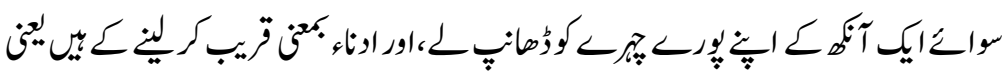

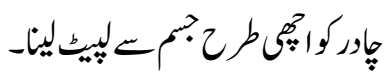

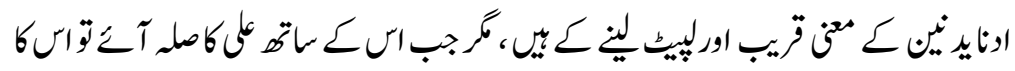

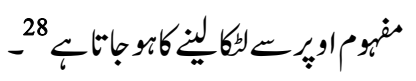

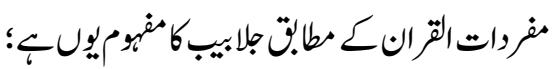

"الجلابيب والقمص والخمر، الواحد جلباب"

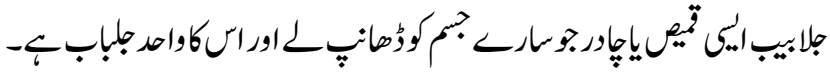

"الجلباب،وجمعاه جلابيب:الرداء الذى يستر من فوق إلى أسفل أو كل ما يُستتر به"

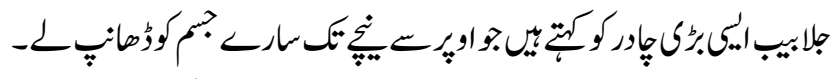

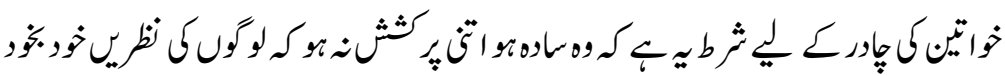

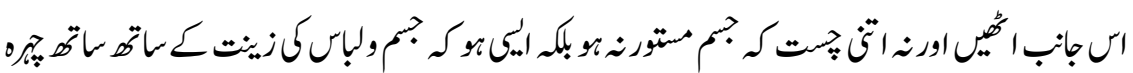

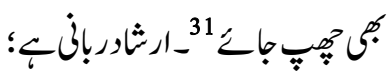

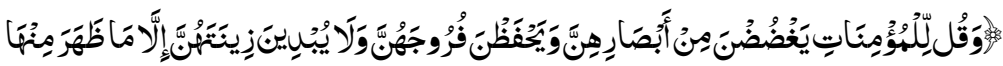

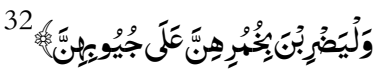

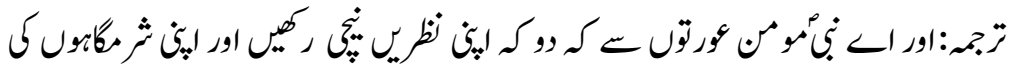

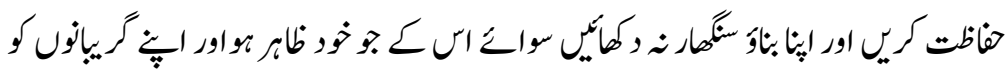

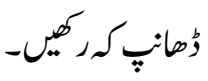

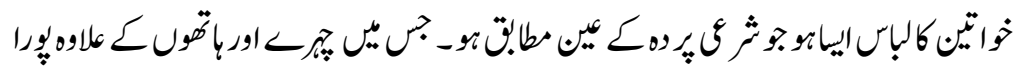

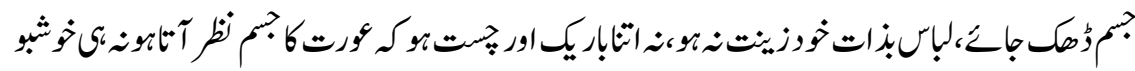

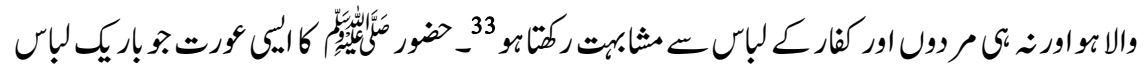

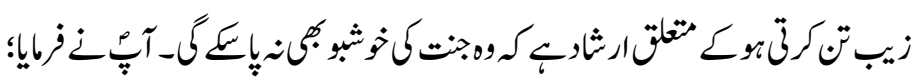




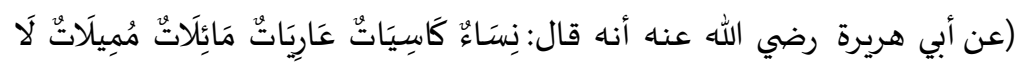

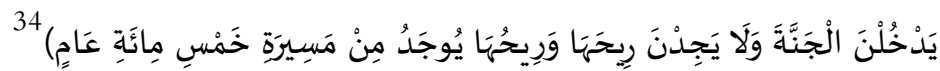

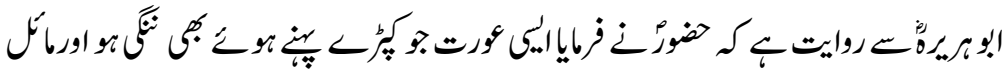

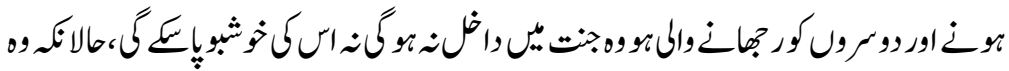

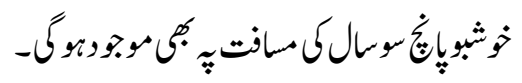

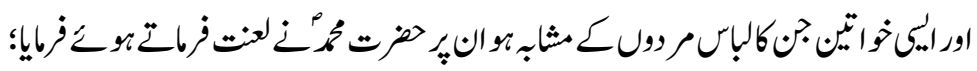

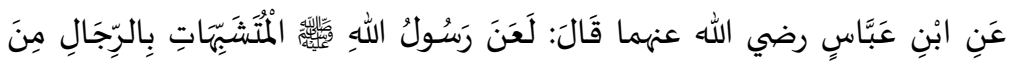

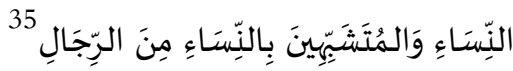

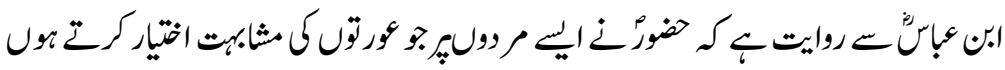

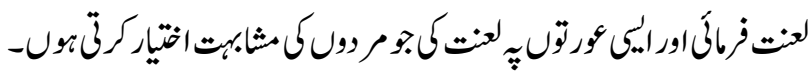

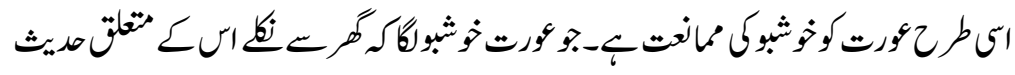

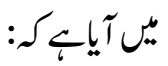

"والمرأة إذا استعطرت فمرت بالمجلس فهي كذا وكذا يعني زانية"

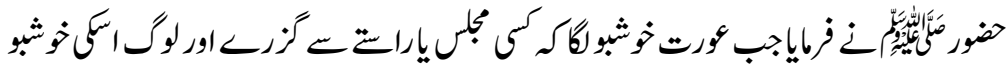

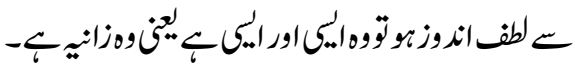

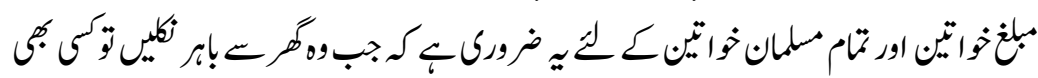

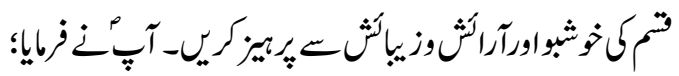

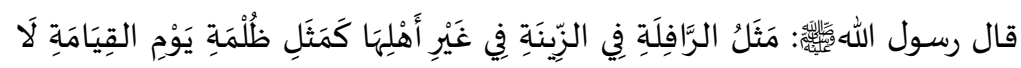
نُورَ لَهَانَ

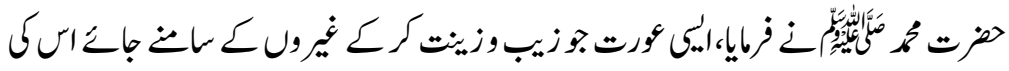

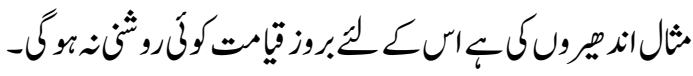

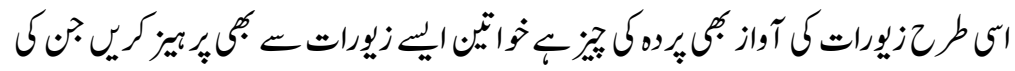

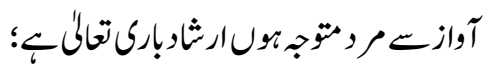

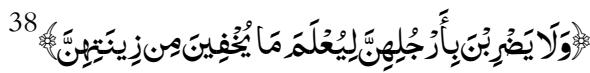

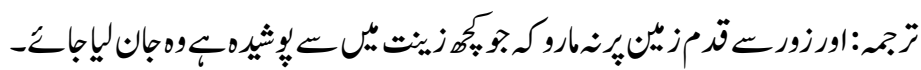




\section{ؤورنوكى آواز}

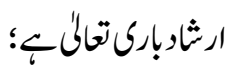

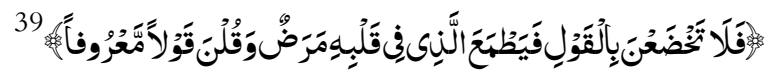

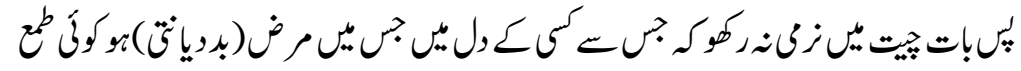

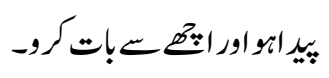

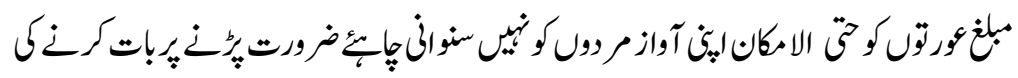

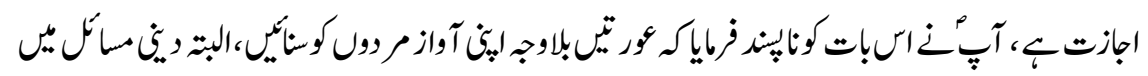

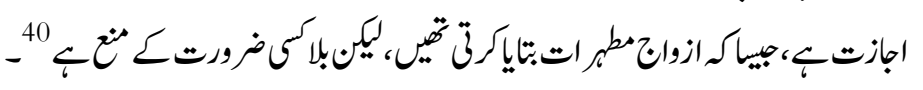

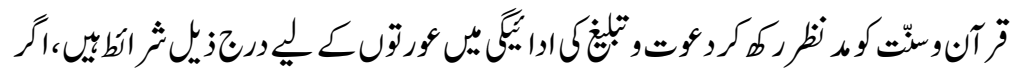

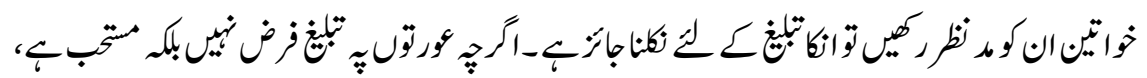

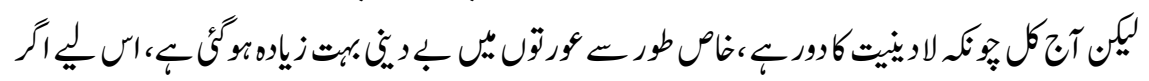

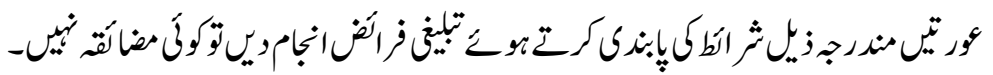

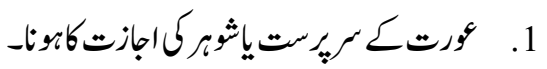

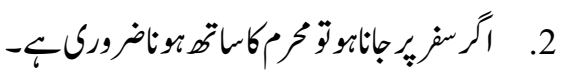

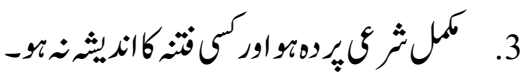

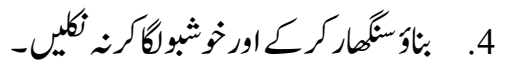

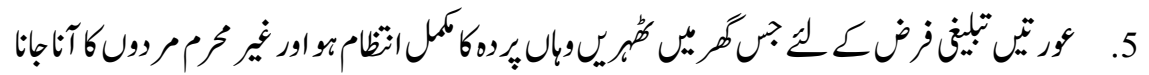

$$
{ }^{41}-96 \dot{0}
$$

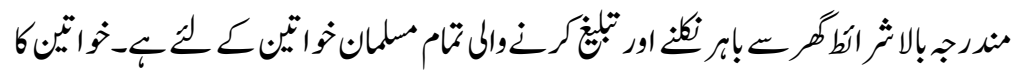

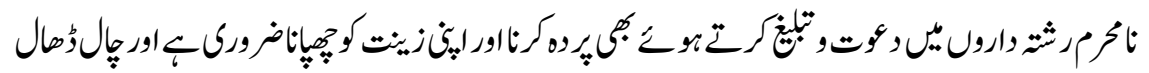

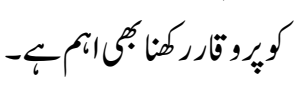

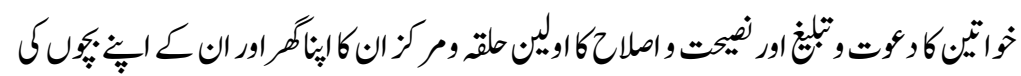

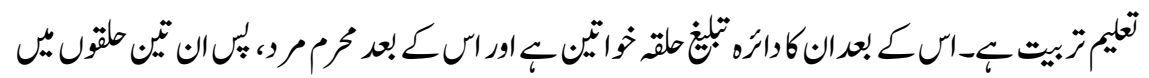




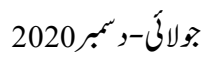

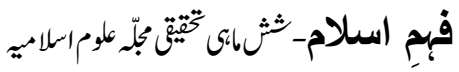

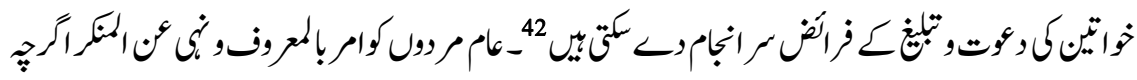

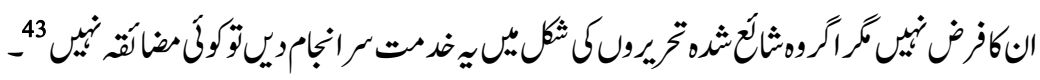

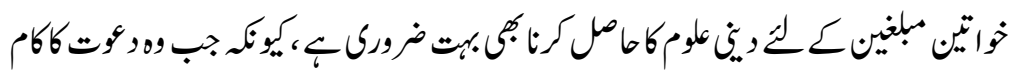

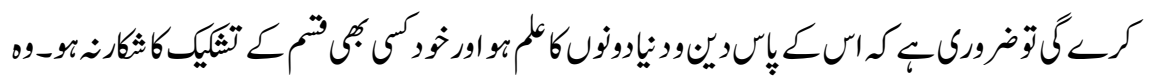

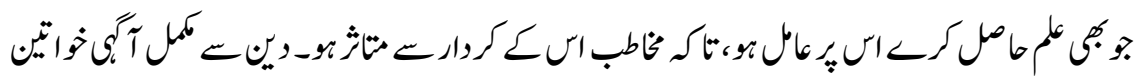

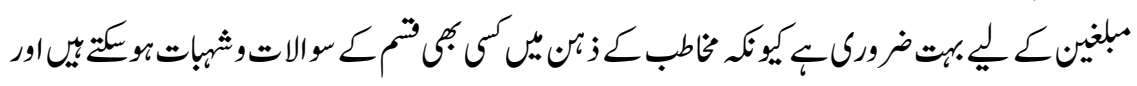

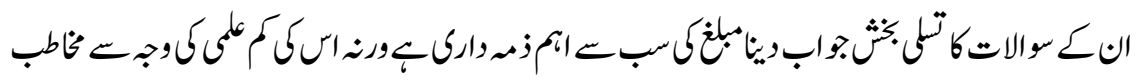

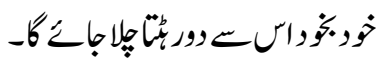

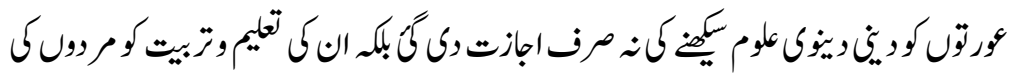

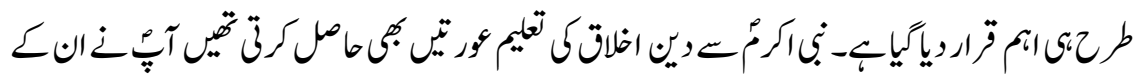

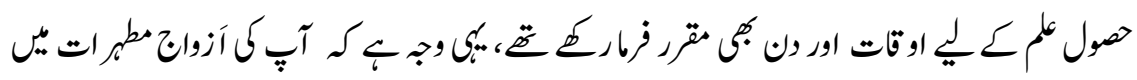

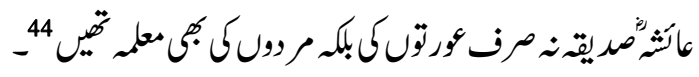

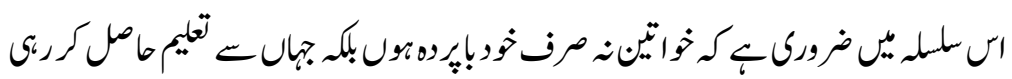

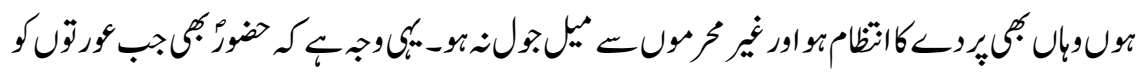

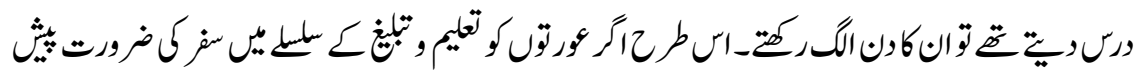

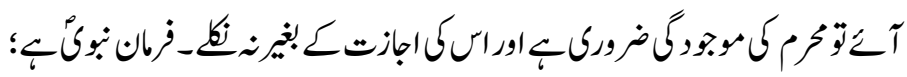

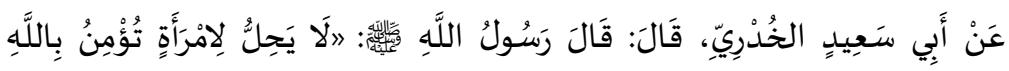

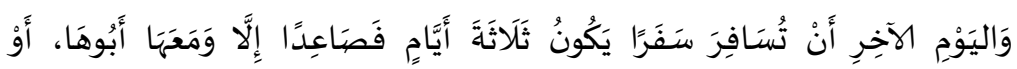

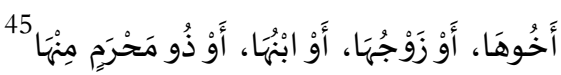

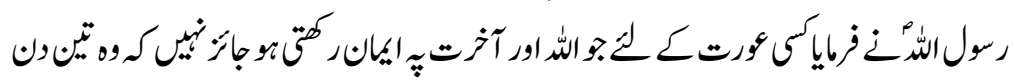

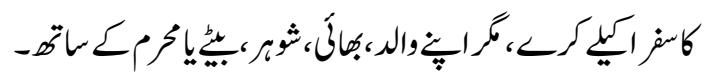

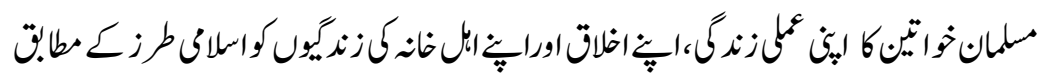

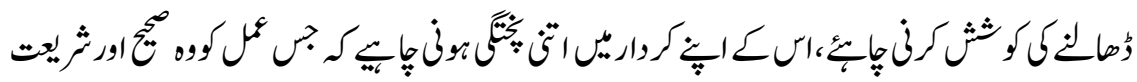

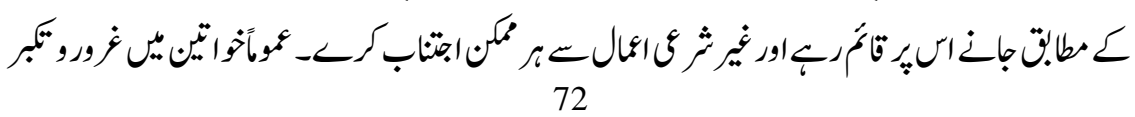




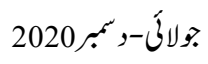

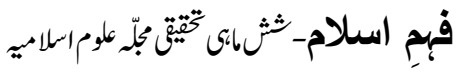

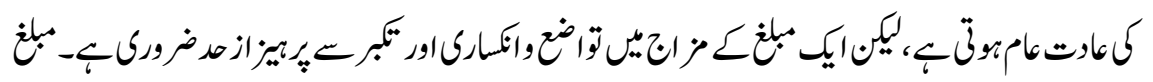

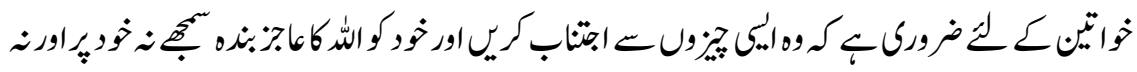

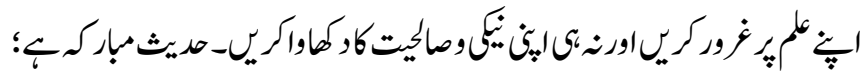

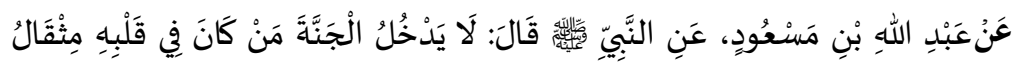
ذَرَّةٍ مِنْ كِنْبِ 46

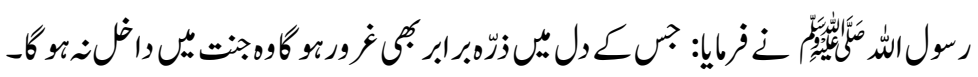

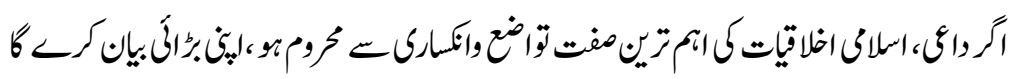

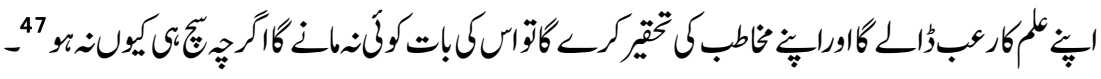

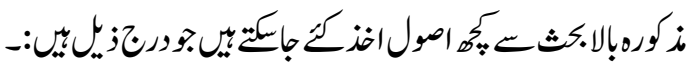
1

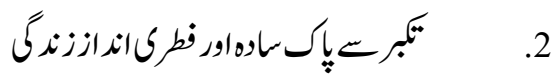

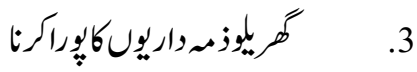

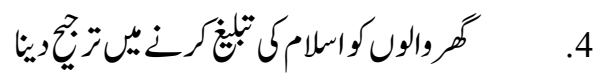

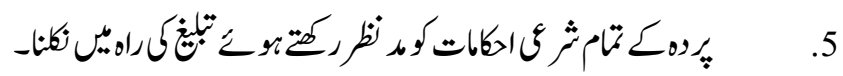

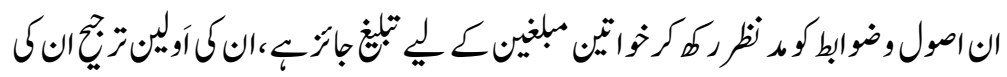

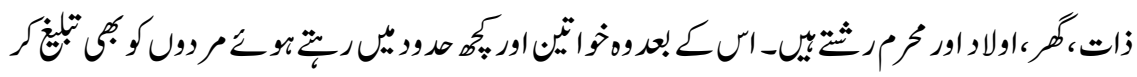

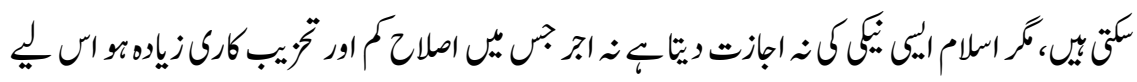

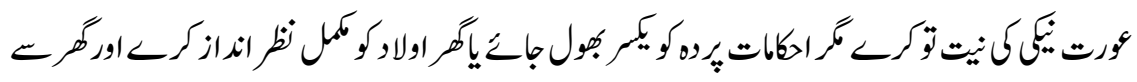

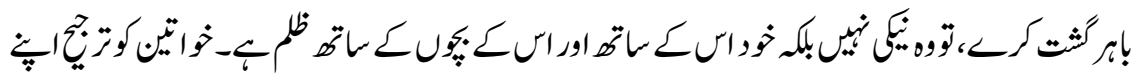

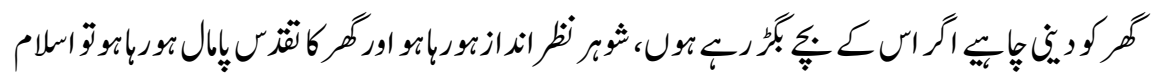

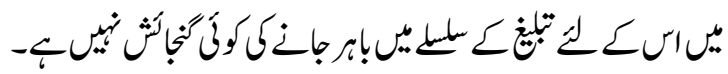

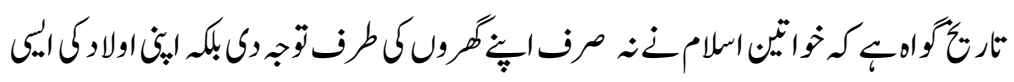

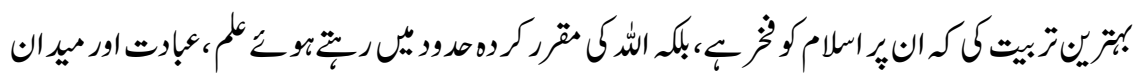

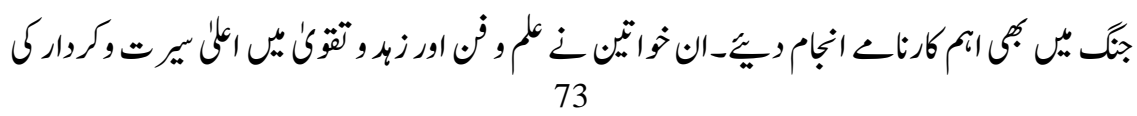




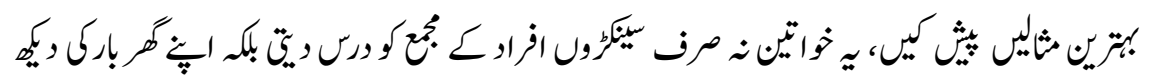

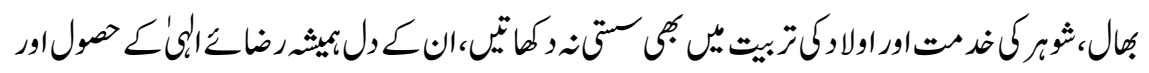

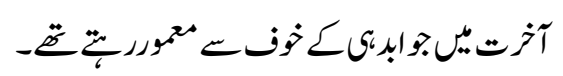

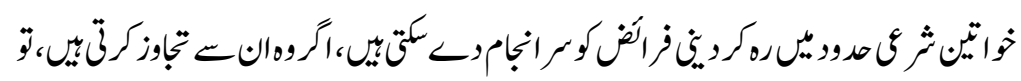

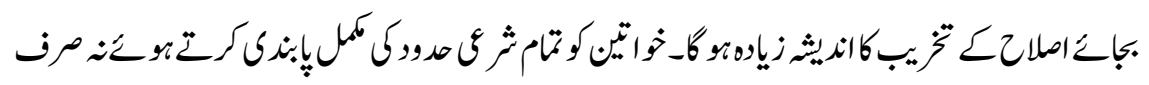

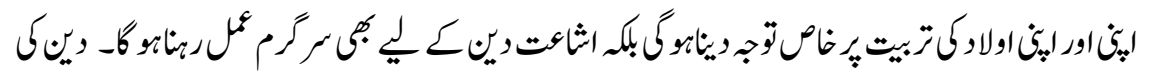

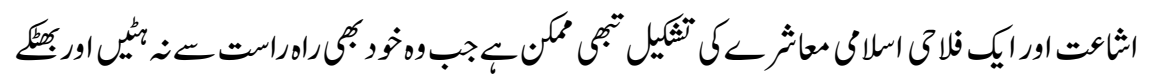

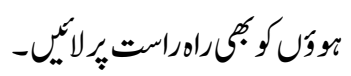

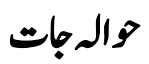

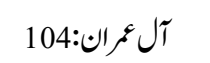

2 3 4 5 7 8

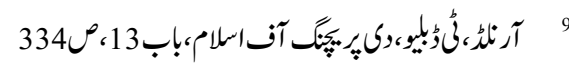
10 11

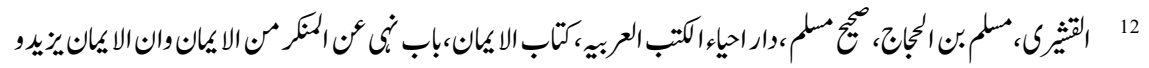

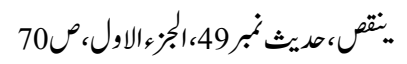

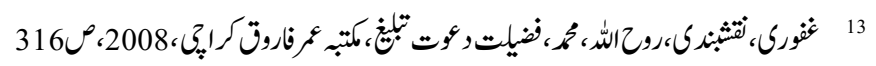

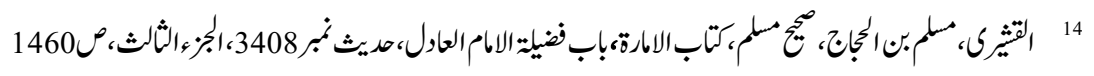




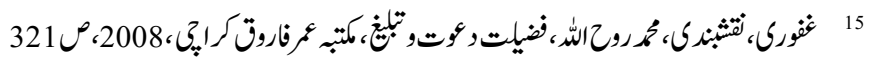

$$
\begin{aligned}
& 16 \text { التّام:6 } \\
& 18
\end{aligned}
$$

${ }^{21}$.A short history of Islam.p18

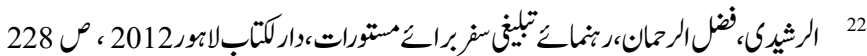

$$
\begin{aligned}
& \text { 33:23 الإناب }
\end{aligned}
$$

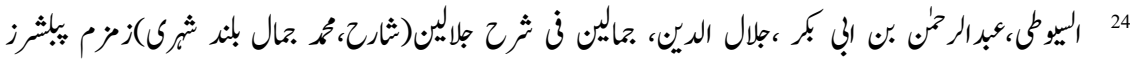

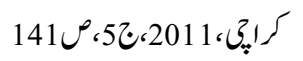

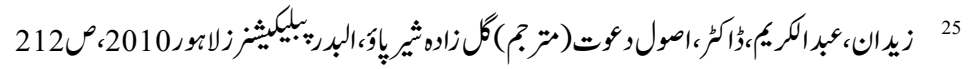

$$
26
$$

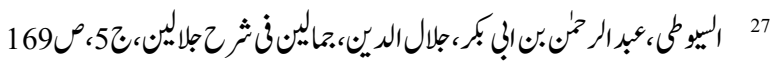

28

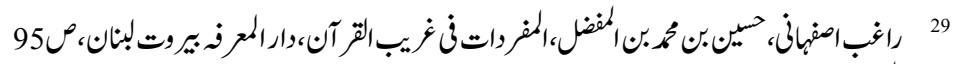

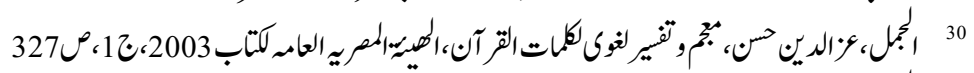

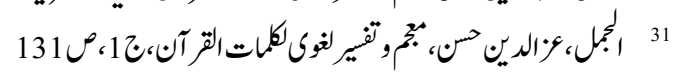

$$
32
$$

$$
33
$$

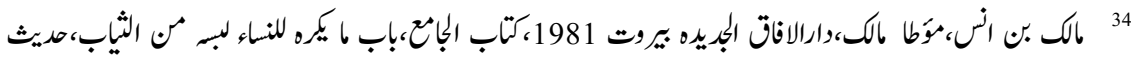

$$
\text { 893 } 52
$$

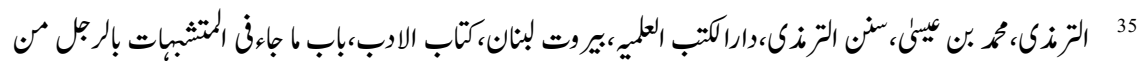

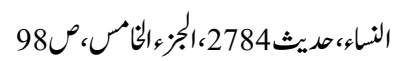

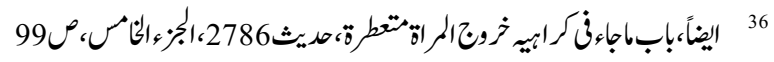

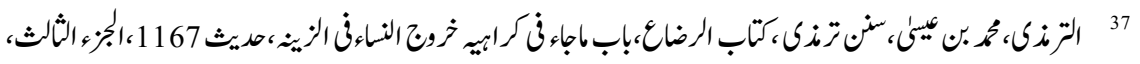




$$
\begin{aligned}
& 31: 38 \\
& 39 \\
& 40 \\
& 41 \\
& 42
\end{aligned}
$$

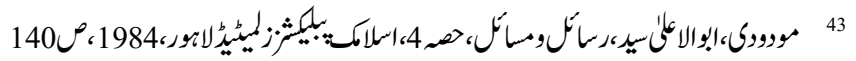

$$
\begin{aligned}
& 44
\end{aligned}
$$

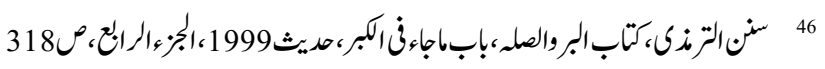

$$
\begin{aligned}
& 47
\end{aligned}
$$

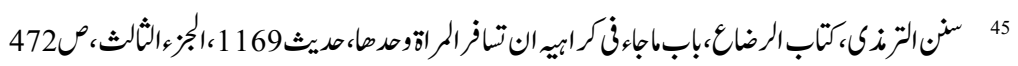

